\title{
Dry Matter Yield, Content, Uptake and Partitioning of NPK by Papaya as Affected by Organic and INM System under South Gujarat, India
}

\author{
A.P. Italiya ${ }^{*}$, Narendra Singh, S.K. Desai, P.S. Patel and T.U. Patel \\ Department of Soil Science and Agricultural Chemistry, College of Agriculture, Navsari \\ Agriculture University, Bharuch, Gujarat, India \\ *Corresponding author
}

\begin{tabular}{|l|}
\hline K e y w o r d s \\
$\begin{array}{l}\text { Papaya, Yield } \\
\text { attributes, Quality, } \\
\text { Organic, } \\
\text { Pseudostem sap. } \\
\text { INM. }\end{array}$ \\
\hline Article Info \\
\hline $\begin{array}{l}\text { Accepted: } \\
\text { 23 July 2017 } \\
\text { Available Online: } \\
\text { 10 September } 2017\end{array}$ \\
\hline
\end{tabular}

\section{Introduction}

Papaya is native to tropical America and is believed to have originated in Southern Mexico. It belongs to the family Caricaceae and according to Purseglove (1968), it is probably originated in Southern Mexico and Costa Rica. Papaya (Carica papaya Linn.) is an important fruit crop of tropical world and has long been known as wonderful fruit of the tropics. Papaya is the fifth important fruit crop of India. It gives higher production of fruits per hectare and an income next to banana (NHB, 2014).

In India, papaya is successfully grown all over country and is available round the year. It occupies 98,000 hectares of cultivated area with 3629 thousand tonnes of production. The country's average productivity of papaya is 37.1 t/ha (Anon., 2012). In India, the important papaya growing states are Andhra 
Pradesh, Kerala, Tamil Nadu, Orissa, Assam, West Bengal, Gujarat and Maharashtra. These states are having ideal climatic conditions for its growth and production. However, in Gujarat its average productivity is $51.18 \mathrm{t} / \mathrm{ha}$. It is cultivated on an estimated area of 14,100 hectares with production of 721.7 thousand tonnes (Anon., 2012).

Papaya crop being heavy feeder and the fruit are harvested fresh, the nutrient requirement of this crop is also very high. Growing papaya crop under organic farming can be possible only if integration of different sources of organics is done in such way that the nutrient release pattern matches with the nutrients demands of the crop. According to agroclimatic situation, the climate of south Gujarat zone is typically tropical, characterized by humid and warm monsoon with heavy rainfall, moderately cold winter and fairly hot and humid summer. The average annual rainfall of the tract is about $1500 \mathrm{~mm}$. The work done in India is predominately related to INM and very scanty literature is available on nutrient management in pure organic farming. Scrutinizing literature available on organic farming showed that in general people are using single bulky source of organic manure (Reddy et al., 2010). Information regarding these aspect is very scanty under South Gujarat and more so under organic farming situation. Hence, present study was planned to assess the effect of different proportion of organics with and without sap on yield and quality of papaya grown on organic farm.

\section{Materials and Methods}

A field experiment consisting of eight treatment combinations involving different proportion of three organics on $\mathrm{N}$ equivalent basis $\left[\mathrm{O}_{1}: 50 \% \mathrm{RDN}\right.$ through bio compost (BC) $+50 \%$ RDN through castor cake (CC), $\mathrm{O}_{2}: 50 \%$ RDN through bio compost $+50 \%$ RDN through vermi compost (VC), $\mathrm{O}_{3}: 50 \%$
RDN through bio compost $+25 \%$ RDN through vermi compost $+25 \%$ through castor cake and $\mathrm{O}_{4}: 33.3 \%$ RDN through bio compost $+33.3 \%$ RDN through vermi compost $+33.4 \%$ RDN through castor cake] and two levels of banana pseudostem sap application $\left(\mathrm{S}_{0}\right.$ : without sap and $\mathrm{S}_{1}$ : with sap @ 8 1/plant) along with one INM controls outside the organic farm were tested in FRBD with three replications at Organic Farm, Fblock, NAU, Navsari during 2009-10 and 2010-11.

Plants sample collected at the time of harvest were first air-dried and then oven dried at 65 ${ }^{0} \mathrm{C}$ till reaches the constant weight and powdered with the help of stainless steel mixture grinder. The powdered samples were stored in plastic bags and were used for analyzing method describe for $\mathrm{N}$ by Warnke and Barber (1974) as well as $\mathrm{P}$ and $\mathrm{K}$ by Jackson (1979).

\section{Results and Discussion}

\section{Dry matter yield}

The pooled results pertaining to dry matter yield of petiole, leaves and fruit of papaya under different treatments are reported in table 1 . The perusal of results indicated that neither individual nor interactive effect of $\mathrm{O}$ and $S$ could influence the dry matter yield of petiole and leaves significantly except fruit dry matter yield of papaya. Among the different organics treatments, application of organics as per $\mathrm{O}_{4}$ treatment recorded significantly higher fruit dry matter yield (103.24 q/ha) of papaya as compared to $\mathrm{O}_{1}$, $\mathrm{O}_{2}$ and $\mathrm{O}_{3}$. Similar variation in papaya fruit yield due to different sources of organics viz., FYM, urban compost, rural compost, sun hemp green manure and Vermicompost have also been reported by Reddy et al., (2010). Like organics, sap effect was also significant and treatment $S_{1}$ recorded significantly higher 
fruit dry matter yield $(96.20 \mathrm{q} / \mathrm{ha})$ in comparison to no application of sap $\left(S_{0}\right)$. Similar beneficial effect of sap application on yields of banana (3 1/plant), sugarcane (5000 1/ha) and onion (1500 1/ha) have also been observed with INM system under South Gujarat conditions (Anon., 2012). In all the cases, the interaction effect between $\mathrm{O}$ and $\mathrm{S}$ was absent. But, between the two i.e., INM control and means of organics treatments, INM control recorded significantly higher dry matter yield of petiole (17.68 q/ha), leaves $(5.05 \mathrm{q} / \mathrm{ha})$ and fruit $(120.10 \mathrm{q} / \mathrm{ha})$ of papaya as compared to means of organics treatments.

\section{Content, uptake and partitioning of $\mathrm{N}, \mathrm{P}$ and $K$}

The N, P and $\mathrm{K}$ content in petiole, leaves and fruit of papaya were affected significantly due to individual effect of $\mathrm{O}$ except $\mathrm{P}$ and $\mathrm{K}$ content of petiole and leaves (Table 2). Treatment $\mathrm{O}_{4}$ recorded significantly higher level of $\mathrm{N}$ content in petiole, leaves and fruit of papaya with a value of $0.961 \%, 3.50 \%$ and $0.171 \%$, respectively, however, significantly higher content of $\mathrm{P}(0.024 \%)$ and $\mathrm{K}(0.280 \%)$ over rest of the organic treatment except O3. These results clearly indicated that when the bulky (BC, VC) and concentrated (CC) organic sources are used in equal proportion, it enhances translocation of nutrients from vegetative parts to reproductive parts. This might be one of the reasons for recording significantly higher content under $\mathrm{O} 4$ treatment as compared to $\mathrm{O} 2$ and O1. Similar results were also reported by Reddy et al., (2010) who used combination of FYM and Sun hemp.

Similarly, application of banana pseudostem sap $\left(S_{1}\right)$ found significant in $N, P$ and $K$ content of petiole, leaves and fruit of papaya over no application of sap $\left(\mathrm{S}_{0}\right)$ except $\mathrm{P}$ content in petiole. The magnitude of significant increased was found with $\mathrm{S}_{1}$ for $\mathrm{N}$, $\mathrm{P}$ and $\mathrm{K}$ content $(3.486 \%, 0.557 \%$ and 2.496 , respectively) in leaves, $\mathrm{N}, \mathrm{P}$ and $\mathrm{K}$ content $(0.178 \%, 0.025 \%$ and $0.267 \%$, respectively) in fruit of papaya as well as $\mathrm{N}$ and $\mathrm{K}$ content $(0.947 \%$ and $3.256 \%$, respectively) in petiole over $\mathrm{S}_{0}$. As far as interaction effect of $\mathrm{O} \times \mathrm{S}$ is concerned, $\mathrm{O}_{4} \mathrm{~S}_{1}(3.702 \%)$ was significantly higher than rest of the combinations with respect to $\mathrm{N}$ content in leaves. In case of control v/s rest analysis, mean of organics showed significant effect on $\mathrm{N}, \mathrm{P}$ and $\mathrm{K}$ content of petiole, leaves and fruit of papaya.

Table.1 Effect of different treatments on dry matter (q/ha) yield of petiole, leaf lamina and fruit (Pooled)

\begin{tabular}{|c|c|c|c|c|c|c|}
\hline Treatments & \multicolumn{2}{|c|}{ Petiole } & \multicolumn{2}{|c|}{ Leaf lamina } & \multicolumn{2}{|c|}{ Fruit } \\
\hline $\mathbf{O}_{1}$ & \multicolumn{2}{|c|}{14.02} & \multicolumn{2}{|c|}{4.00} & \multicolumn{2}{|c|}{78.39} \\
\hline $\mathbf{O}_{2}$ & \multicolumn{2}{|c|}{14.59} & \multicolumn{2}{|c|}{4.17} & \multicolumn{2}{|c|}{86.26} \\
\hline $\mathrm{O}_{3}$ & \multicolumn{2}{|c|}{14.32} & \multicolumn{2}{|c|}{4.09} & \multicolumn{2}{|c|}{97.45} \\
\hline $\mathbf{O}_{4}$ & \multicolumn{2}{|c|}{15.01} & \multicolumn{2}{|c|}{4.29} & \multicolumn{2}{|c|}{103.24} \\
\hline $\mathbf{S}_{\mathbf{0}}$ & \multicolumn{2}{|c|}{14.44} & \multicolumn{2}{|c|}{4.12} & \multicolumn{2}{|c|}{86.47} \\
\hline $\mathbf{S}_{1}$ & \multicolumn{2}{|c|}{14.53} & \multicolumn{2}{|c|}{4.15} & \multicolumn{2}{|c|}{96.20} \\
\hline Mean of Organic & \multicolumn{2}{|c|}{14.49} & \multirow{2}{*}{\multicolumn{2}{|c|}{$\frac{4.14}{5.05}$}} & \multicolumn{2}{|c|}{91.34} \\
\hline Mean of Control & \multicolumn{2}{|c|}{17.68} & & & \multicolumn{2}{|c|}{120.10} \\
\hline Source & SEm \pm & CD at $5 \%$ & \multicolumn{2}{|r|}{ CD at $5 \%$} & SEm \pm & CD at $5 \%$ \\
\hline $\mathbf{O}$ & 0.42 & NS & 0.12 & NS & 1.05 & 3.03 \\
\hline $\mathbf{S}$ & 0.30 & NS & 0.08 & NS & 1.48 & 4.29 \\
\hline $\mathbf{O} \times \mathrm{S}$ & 0.59 & NS & 0.17 & NS & 2.09 & NS \\
\hline Cont. v/s rest & 0.41 & 1.18 & 0.12 & 0.34 & 1.47 & 4.23 \\
\hline CV \% & \multicolumn{2}{|c|}{10} & \multicolumn{2}{|c|}{10} & \multicolumn{2}{|c|}{6} \\
\hline
\end{tabular}


Table.2 Effect of different treatments on N, P and K content (\%) by petiole, leaves and fruit of papaya (Pooled)

\begin{tabular}{|c|c|c|c|c|c|c|c|c|c|c|c|c|c|c|c|c|c|c|}
\hline \multirow{2}{*}{$\begin{array}{c}\text { Treatment } \\
\text { S }\end{array}$} & \multicolumn{6}{|c|}{$\mathbf{N}$} & \multicolumn{6}{|c|}{$\mathbf{P}$} & \multicolumn{6}{|c|}{$\mathbf{K}$} \\
\hline & \multicolumn{2}{|c|}{ Petiole } & \multicolumn{2}{|c|}{ Leaf lamina } & \multicolumn{2}{|c|}{ Fruit } & \multicolumn{2}{|c|}{ Petiole } & \multicolumn{2}{|c|}{ Leaf lamina } & \multicolumn{2}{|c|}{ Fruit } & \multicolumn{2}{|c|}{ Petiole } & \multicolumn{2}{|c|}{ Leaf lamina } & \multicolumn{2}{|c|}{ Fruit } \\
\hline $\mathbf{O}_{1}$ & \multicolumn{2}{|c|}{0.884} & \multicolumn{2}{|c|}{3.255} & \multicolumn{2}{|c|}{0.161} & \multicolumn{2}{|c|}{0.321} & \multicolumn{2}{|c|}{0.515} & \multicolumn{2}{|c|}{0.020} & \multicolumn{2}{|c|}{3.045} & \multicolumn{2}{|c|}{2.347} & \multicolumn{2}{|c|}{0.228} \\
\hline $\mathrm{O}_{2}$ & \multicolumn{2}{|c|}{0.910} & \multicolumn{2}{|c|}{3.346} & \multicolumn{2}{|c|}{0.159} & \multicolumn{2}{|c|}{0.342} & \multicolumn{2}{|c|}{0.531} & \multicolumn{2}{|c|}{0.022} & \multicolumn{2}{|c|}{3.119} & \multicolumn{2}{|c|}{2.299} & \multicolumn{2}{|c|}{0.242} \\
\hline $\mathrm{O}_{3}$ & \multicolumn{2}{|c|}{0.945} & 3.4 & & 0.1 & & & & & & & & 3. & & 2.3 & & & \\
\hline $\mathrm{O}_{4}$ & 0. & & 3.5 & & 0.1 & & & & & & & & 3.2 & & 2.4 & & & \\
\hline$S_{0}$ & & & 3.2 & & 0.1 & & & & & & & & 3. & & 2.2 & & & \\
\hline$S_{1}$ & & & 3.4 & & 0.1 & & & & & & & & 3.2 & & 2.4 & & & \\
\hline Mean of $O$ & & & 3.3 & & 0.1 & & & & & & & & 3. & & 2.3 & & & \\
\hline Mean of $\mathrm{C}$ & & & 2.9 & & 0.1 & & & & & & & & 2.2 & & 2.1 & & & \\
\hline Source & SEm \pm & CD & SEm \pm & CD & SEm \pm & CD & SEm \pm & CD & SEm \pm & CD & SEm \pm & CD & SEm \pm & CD & SEm \pm & CD & SEm \pm & CD \\
\hline $\mathbf{O}$ & 0.011 & 0.031 & 0.031 & 0.089 & 0.003 & 0.008 & 0.012 & NS & 0.016 & $\mathrm{NS}$ & 0.001 & 0.002 & 0.085 & $\mathrm{NS}$ & 0.053 & NS & 0.006 & 0.018 \\
\hline $\mathbf{S}$ & 0.015 & 0.044 & 0.043 & 0.126 & 0.002 & 0.006 & 0.008 & NS & 0.011 & 0.033 & 0.001 & 0.002 & 0.060 & 0.174 & 0.038 & 0.109 & 0.004 & 0.013 \\
\hline $\mathrm{O} \times \mathrm{S}$ & 0.021 & NS & 0.061 & 0.178 & 0.004 & NS & 0.017 & NS & 0.023 & NS & 0.001 & NS & 0.120 & NS & 0.075 & NS & 0.009 & NS \\
\hline $\begin{array}{c}\text { Cont. v/s } \\
\text { rest }\end{array}$ & 0.014 & 0.041 & 0.042 & 0.121 & 0.003 & 0.007 & 0.012 & 0.034 & 0.017 & 0.049 & 0.001 & 0.002 & 0.080 & 0.229 & 0.050 & 0.145 & 0.006 & 0.017 \\
\hline CV \% & & & 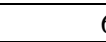 & & 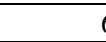 & & & & & & & & 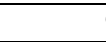 & & 8 & & & \\
\hline
\end{tabular}

Table.3 Effect of different treatments on N, P and K uptake (kg/ha) by petiole, leaves and fruit of papaya (Pooled)

\begin{tabular}{|c|c|c|c|c|c|c|c|c|c|c|c|c|c|c|c|c|c|c|}
\hline \multirow{2}{*}{$\begin{array}{c}\text { Treatment } \\
\text { S }\end{array}$} & \multicolumn{6}{|c|}{$\mathbf{N}$} & \multicolumn{6}{|c|}{$\mathbf{P}$} & \multicolumn{6}{|c|}{$\mathbf{K}$} \\
\hline & \multicolumn{2}{|c|}{ Petiole } & \multicolumn{2}{|c|}{ Leaf lamina } & \multicolumn{2}{|c|}{ Fruit } & \multicolumn{2}{|c|}{ Petiole } & \multicolumn{2}{|c|}{ Leaf lamina } & \multicolumn{2}{|c|}{ Fruit } & \multicolumn{2}{|c|}{ Petiole } & \multicolumn{2}{|c|}{ Leaf lamina } & \multicolumn{2}{|c|}{ Fruit } \\
\hline $\mathrm{O}_{1}$ & \multicolumn{2}{|c|}{12.41} & \multicolumn{2}{|c|}{13.05} & \multicolumn{2}{|c|}{12.66} & \multicolumn{2}{|c|}{4.50} & \multicolumn{2}{|c|}{2.06} & \multicolumn{2}{|c|}{1.57} & \multicolumn{2}{|c|}{42.79} & \multicolumn{2}{|c|}{9.40} & \multicolumn{2}{|c|}{17.89} \\
\hline $\mathbf{O}_{2}$ & \multicolumn{2}{|c|}{13.27} & \multicolumn{2}{|c|}{13.95} & \multicolumn{2}{|c|}{13.80} & \multicolumn{2}{|c|}{5.00} & \multicolumn{2}{|c|}{2.21} & \multicolumn{2}{|c|}{1.90} & \multicolumn{2}{|c|}{45.62} & \multicolumn{2}{|c|}{9.58} & \multicolumn{2}{|c|}{20.91} \\
\hline $\mathrm{O}_{3}$ & \multicolumn{2}{|c|}{13.57} & 14 & & 15 & & & & 2. & & & & & & 9.8 & & & \\
\hline $\mathrm{O}_{4}$ & & & 15 & & 17 & & & & 2. & & & & & & 10. & & & \\
\hline$S_{0}$ & & & 13 & & 12 & & & & 2. & & & & & & 9.2 & & & \\
\hline$S_{1}$ & & & 14 & & 17 & & & & 2. & & & & & & 10. & & & \\
\hline Mean of $\mathrm{O}$ & & & 14 & & 15 & & & & 2. & & & & & & 9.8 & & & \\
\hline Mean of C & & & 14 & & 16 & & & & 2. & & & & & & 10. & & & \\
\hline Source & SEm \pm & CD & SEm \pm & CD & SEm \pm & CD & SEm \pm & CD & SEm \pm & CD & SEm \pm & CD & SEm \pm & CD & SEm \pm & CD & SEm \pm & CD \\
\hline $\mathbf{O}$ & 0.43 & 1.25 & 0.47 & NS & 0.33 & 0.96 & 0.23 & 0.66 & 0.09 & $\mathrm{NS}$ & 0.07 & 0.20 & 2.01 & NS & 0.35 & $\mathrm{NS}$ & 0.67 & 1.94 \\
\hline $\mathbf{S}$ & 0.31 & NS & 0.33 & 0.96 & 0.23 & 0.68 & 0.16 & $\mathrm{NS}$ & 0.06 & 0.18 & 0.05 & 0.14 & 1.42 & $\mathrm{NS}$ & 0.25 & 0.72 & 0.47 & 1.37 \\
\hline $\mathrm{O} \times \mathrm{S}$ & 0.61 & NS & 0.66 & NS & 0.47 & 1.35 & 0.32 & NS & 0.12 & $\mathrm{NS}$ & 0.10 & $\mathrm{NS}$ & 2.84 & NS & 0.50 & $\mathrm{NS}$ & 0.95 & 2.75 \\
\hline $\begin{array}{c}\text { Cont. v/s } \\
\text { rest }\end{array}$ & 0.42 & NS & 0.45 & NS & 0.33 & NS & 0.23 & NS & 0.09 & NS & 0.07 & NS & 1.90 & NS & 0.34 & NS & 0.66 & NS \\
\hline $\mathrm{CV} \%$ & & & 1 & & $\varepsilon$ & & & & 1 & & & & & & 1 & & & \\
\hline
\end{tabular}

Note: $\mathrm{CD}$ is at $5 \%$ 
Table.4 Petiole, leaves and fruit N, P and K partitioning

\begin{tabular}{|c|c|c|c|c|c|c|c|c|}
\hline \multirow{2}{*}{$\begin{array}{c}\text { Plant } \\
\text { component }\end{array}$} & \multicolumn{4}{|c|}{ Organics } & \multicolumn{2}{|c|}{ Sap } & \multirow{2}{*}{$\begin{array}{c}\text { O- } \\
\text { Mean }\end{array}$} & \multirow{2}{*}{ INM } \\
\hline & $O_{1}$ & $\mathbf{O}_{2}$ & $\mathrm{O}_{3}$ & $\mathbf{O}_{4}$ & $\mathbf{S}_{\mathbf{0}}$ & $S_{1}$ & & \\
\hline \multicolumn{9}{|c|}{$\mathbf{N}$} \\
\hline Petiole & 32.56 & 32.35 & 31.22 & 30.51 & 33.09 & 30.28 & 31.59 & 31.99 \\
\hline Leaves & 34.23 & 34.01 & 32.28 & 31.80 & 34.25 & 31.91 & 33.00 & 32.53 \\
\hline Fruits & 33.21 & 33.64 & 36.51 & 37.69 & 32.66 & 37.81 & 35.41 & 35.48 \\
\hline Total & 100 & 100 & 100 & 100 & 100 & 100 & 100 & 100 \\
\hline \multicolumn{9}{|c|}{$\mathbf{P}$} \\
\hline Petiole & 55.35 & 54.88 & 53.12 & 53.08 & 55.99 & 52.28 & 54.05 & 55.57 \\
\hline Leaves & 25.34 & 24.26 & 23.60 & 22.83 & 24.54 & 23.40 & 23.95 & 24.30 \\
\hline Fruits & 19.31 & 20.86 & 23.28 & 24.08 & 19.47 & 24.32 & 22.01 & 20.13 \\
\hline Total & 100 & 100 & 100 & 100 & 100 & 100 & 100 & 100 \\
\hline \multicolumn{9}{|c|}{$\mathbf{K}$} \\
\hline Petiole & 61.06 & 59.94 & 56.81 & 54.96 & 59.51 & 56.70 & 58.00 & 55.84 \\
\hline Leaves & 13.41 & 12.59 & 12.29 & 11.95 & 12.69 & 12.36 & 12.51 & 13.77 \\
\hline Fruits & 25.53 & 27.47 & 30.90 & 33.09 & 27.80 & 30.93 & 29.48 & 30.39 \\
\hline Total & 100 & 100 & 100 & 100 & 100 & 100 & 100 & 100 \\
\hline
\end{tabular}

The uptake of $\mathrm{N}$ and $\mathrm{P}$ through petiole as well as $\mathrm{N}, \mathrm{P}$ and $\mathrm{K}$ through fruit of papaya was affected significantly due application of different proportion of organics.

The magnitude of significance in uptake of $\mathrm{N}$ $(14.39 \mathrm{~kg} / \mathrm{ha})$ and $\mathrm{P}(5.51 \mathrm{~kg} / \mathrm{ha})$ through petiole as well as $\mathrm{N}(17.78 \mathrm{~kg} / \mathrm{ha}), \mathrm{P}(2.50$ $\mathrm{kg} / \mathrm{ha})$ and $\mathrm{K}(29.00 \mathrm{~kg} / \mathrm{ha})$ through fruit of papaya was found with treatment $\mathrm{O}_{4}$, however, it was at par with $\mathrm{O}_{3}$ with respect to $\mathrm{N}$ and $\mathrm{P}$ uptake by petiole. Application of banana pseudo stem sap showed significantly higher uptake of $\mathrm{N}(14.49$ and $17.17 \mathrm{~kg} / \mathrm{ha}), \mathrm{P}$ $(5.16$ and $2.31 \mathrm{~kg} / \mathrm{ha})$ and $\mathrm{K}(10.36$ and 25.92 $\mathrm{kg} / \mathrm{ha}$ ) through leaves and fruit of papaya, respectively. The $\mathrm{N}$ and $\mathrm{K}$ uptake by fruit of papaya showed significant variation due to $\mathrm{O}$ $\mathrm{x} \mathrm{S}$, however, significantly higher value of $\mathrm{N}$ $(20.75 \mathrm{~kg} / \mathrm{ha})$ and $\mathrm{P}(33.28 \mathrm{~kg} / \mathrm{ha})$ uptake was found with $\mathrm{O}_{4} \mathrm{~S}_{1}$ over rest of the organic treatment combinations. In control $\mathrm{v} / \mathrm{s}$ rest analysis, treatment analysis was turned out to be not significant for uptake of N, P and K through different parts of papaya.
The per cent distribution values (Table 3) clearly revealed that under $\mathrm{O}_{4}$ treatment, the accumulation of $\mathrm{N}, \mathrm{P}$ and $\mathrm{K}$ in fruit with $\mathrm{O}_{4}$ treatment was 37.69, 24.08 and 33.09 per cent as against the respective values recorded with $\mathrm{O}_{1}$ were $33.21,19.31$ and 25.53 per cent. These results clearly indicated that when the bulky (BC, VC) and concentrated (CC) organic sources are used in equal proportion, it enhances translocation of nutrients from vegetative parts to reproductive parts. This might be one of the reasons for recording significantly higher yield under $\mathrm{O}_{4}$ treatment as compared to $\mathrm{O}_{2}$ and $\mathrm{O}_{1}$. Similar results were also reported by Reddy et al., (2010) who used combination of FYM and Sun hemp. In case of sap, the magnitude of increase in accumulation of $\mathrm{N}, \mathrm{P}$ and $\mathrm{K}$ with $\mathrm{S}_{1}$ treatment was $37.81,24.32$ and 30.93 (Table 4). The corresponding values for $\mathrm{S}_{0}$ treatments were $32.66,19.47$ and 27.80 per cent. It seems that the presence of cytokinin and GA3 apart from supplementation of nutrients in sap might have facilitated translocation of nutrient form vegetative to 
reproductive part.

Based on the results of two years field experiments it can be concluded that for achieving higher dry matter yield of papaya with superior quality under organic farming situation of South Gujarat, it is essential to apply bio compost: vermi compost: castor cake in equal proportion to supply $\mathrm{N}$. Application of banana pseudostem sap further enhanced the fruit yield and improved the quality of papaya grown under organic farming situation.

\section{References}

Anonymous, 2012. AGRESCO Report. 8th Meeting of Natural Resources Management (Navsari Agricultural University). 2nd and 3rd April, 2012.

Jackson, M.L., 1979. Soil Chemical Analysis. Prentice Hall of India (Pvt.) Ltd., New
Delhi.

Purseglove, J.W., 1968. Tropical Crops. Dicotyledons; the English Language Book Society, 1: 647.

Reddy, Y. T. N., Kurian, R. M., Ganeshamurthy, A. N and Pannerselvam, P. 2010. Effect of organic nutrition practices on papaya (cv. Surya) fruit yield, quality and soil health. Journal of Horticultural Science, 5(2): 124-127.

Singh, K. K., Barche, S. and Singh, D.B. 2010. Integrated nutrient management in papaya (Carica papaya 1.) Cv. Surya. Acta Horticulturae. (ISHS) 851:377380.

Warnke, D.D., and Barber, S.P. 1974. Root development and nutrient uptake by corn growth in solution culture. Journal of Agronomy, 66: 514.

\section{How to cite this article:}

Italiya, A.P., Narendra Singh, S.K. Desai, P.S. Patel and Patel, T.U. 2017. Dry Matter Yield, Content, Uptake and Partitioning of NPK by Papaya as Affected by Organic and INM System under South Gujarat, India. Int.J.Curr.Microbiol.App.Sci. 6(9): 2118-2123.

doi: https://doi.org/10.20546/ijcmas.2017.609.260 